\title{
Semisynthetic Sphingolipids Prevent Protein Kinase C Translocation and Neuronal Damage in the Perifocal Area following a Photochemically Induced Thrombotic Brain Cortical Lesion
}

\author{
Alexander Kharlamov, Alessandro Guidotti, Erminio Costa, Robert Hayes, and David Armstrong \\ Fidia-Georgetown Institute for the Neurosciences, Georgetown University, School of Medicine, Washington, D.C. 20007
}

A vascular thrombotic lesion localized to the rat sensorimotor cortex was produced following intravenous injection of the photosensitive dye rose bengal, and its activation with a small beam of high-intensity white light focused to the skull overlaying the sensorimotor cortex. In the sensorimotor cortex at various times after the triggering event, two contiguous brain regions with different degree(s) of neuronal damage can be distinguished: (1) a primary thrombotic ischemic core where the majority of cells are dead and (2) a penumbra region surrounding the core lesion in which a slower progressive neuronal degeneration is occurring. Importantly, in both brain regions the neuronal degeneration is associated with the activation and persistent translocation of protein kinase $C$ (PKC) as indicated by an increase in 4- $\beta-3 \mathrm{H}-$ phorbol12,13-dibutyrate ('H-PDBu) binding. Moreover, the demonstration that in the area penumbra the neuronal degeneration and the persistent translocation of PKC can be inhibited by a pretreatment with dizocilpine (i.e., MK-801) indicates that the dynamics of the progression of the neuronal degeneration are maintained by glutamate accumulating in the extraneuronal fluids. MK-801 additionally prevents the transcriptional activation of several immediate-early genes (IEGs) (e.g., c-fos) and their cognate third nuclear messenger (i.e., c-Fos) expression present in the hemisphere ipsilateral to the lesion. On the other hand, LIGA4 and LIGA20 derivatives of GM1 lysoganglioside reduce the membrane translocation of PKC and the neuronal damage in the penumbra area, but fall to change the increase of IEG expression in the cortex ipsilateral to the lesion.

[Key words: focal ischemia, gangliosides, protein kinase C, excitotoxicity, c-Fos, neuronal damage]

Acute focal brain ischemia is an unexpected, sudden event, the preventive treatment of which is virtually impossible. However, one can attempt to reduce pharmacologically the consequences of a focal ischemic/hypoxic brain insult by targeting drugs to events restricted to the area penumbra. This area often lacks precise boundaries, yet surrounds the primary infarcted core and is characterized by edema, reduced blood flow, and reduced glucose utilization and includes damaged neurons at risk of

Received Sept. 28, 1992; revised Dec. 7, 1992; accepted Dec. 10, 1992.

We gratefully acknowledge the technical assistance of Roxanne Sheffield. This work was supported in part by NIH Grants AG08206 and 1RO1 MH40486-01.

Correspondence should be addressed to Erminio Costa, M.D., Fidia-Georgetown Institute for the Neurosciences, Georgetown University, School of Medicine, 3900 Reservoir Road, N.W., Washington, DC 20007.

Copyright $(1993$ Society for Neuroscience $0270-6474 / 93 / 132483-12 \$ 05.00 / 0$ delayed death (Astrup et al., 1981; Dietrich et al., 1986, 1987; Siesjo et al., 1989). Many factors are thought to participate in the induction of neuronal degeneration and death in the area penumbra including reduced oxygen availability, destabilization of free intraneuronal $\mathrm{Ca}^{2+}$ homeostasis, activation of $\mathrm{Ca}^{2+}$. dependent lipases and proteases, excessive production of arachidonic acid metabolites and free radicals, nitric oxide formation (Rothman and Olney, 1987; Choi, 1988; Ginsberg and Busto, 1989; Siesjo and Bengtsson, 1989; Siesjo et al., 1989; Bredt and Snyder, 1992), and, very important, an increase in the interstitial fluid concentration of glutamate and other depolarizing excitotoxins (Benveniste et al., 1984; Rothman and Olney, 1986; Choi and Rothman, 1990).

Glutamate is the major excitatory neurotransmitter in mammalian brain, and during neuronal firing, quanta of this neurotransmitter are released intermittently from nerve terminals (Fonnum, 1991) where they open $\mathrm{Ca}^{2+}$ cationic channels, which in turn results in rapid oscillations of free cytosolic calcium $\left(\left[\mathrm{Ca}^{2+}\right]_{1}\right)$ in the postsynaptic neuron (Connor, 1992; Miller, 1992). These $\left[\mathrm{Ca}^{2+}\right]$ oscillations are generally the consequence of glutamate binding to ionotropic receptors permeable to $\mathrm{Ca}^{2+}$ and $\mathrm{Na}^{+}$or metabotropic receptors coupled to phospholipases, adenylate, and guanylate cyclase (for review, see Manev et al., 1990a). If, however, quanta of glutamate are released from nerve terminals with high frequency and repetitively, such as during an epileptic seizure, the oscillatory behavior of $\left[\mathrm{Ca}^{2+}\right]$, in the activated dendritic region of the postsynaptic neuron becomes impaired, and as a result $\left[\mathrm{Ca}^{2+}\right]$, tends to accumulate within this postsynaptic region (Muller and Connor, 1991; Connor, 1992; Miller, 1992). One of the first events triggered by a sustained accumulation of intraneuronal $\left[\mathrm{Ca}^{2+}\right]$, is the coordinated expression of immediate-early genes (IEGs) (Szekely et al., 1987, 1990). IEGs cncode transcription activating factors, which act as nuclear third messengers and initiate the expression of a variety of nerve growth factors [i.e., brain-derived nerve growth factor (BDNF), NGF] (Dal Toso et al., 1988; Cheng and Mattson, 1991; Comelli et al., 1992) operative in neurotrophic and neuroplastic events, possibly including the modification in the profile of mRNAs encoding for ionotropic receptors expressed in the ncurons (Memo et al., 1991).

However, if ionotropic glutamate receptors are continuously stimulated by high concentrations of interstitial glutamate, as it occurs in the area penumbra during focal brain ischemia, then $\mathrm{Ca}^{2+}$ continues to enter the neurons and diffuse from dendrites to soma (Miller, 1992) where it may contribute to an irreversible destabilization of $\left[\mathrm{Ca}^{2+}\right]$, homeostasis, which in turn shuts off the coordinate expression of IEG, and accelerates a chain of 
pathological biochemical events that may ultimately lead to irreversible structural neuronal damage and death (Rothman and Olney, 1986; Choi, 1988; Siesjo et al., 1989; Manev et al., 1990a). One pathological event, which presumably is triggered by the influx of $\left[\mathrm{Ca}^{2+}\right]$, elicited by abusive glutamate receptor stimulation and contributes to the sustained, protracted, and irreversible destabilization of $\left[\mathrm{Ca}^{2+}\right]$, homeostasis in neurons, is an exaggerated and prolonged membrane translocation and activation of protein kinase C (PKC) (Vaccarino et al., 1987; Manev et al., 1989, 1990a; Favaron et al., 1990; Mattson, 1991).

A melioration of glutamate-induced neuronal damage, including a reduction of $\left[\mathrm{Ca}^{2+}\right]$, homeostasis destabilization, has been observed following (1) an acute pretreatment of neurons in vitro with staurosporine and $\mathrm{H} 7$, two substrate competitive $\mathrm{PKC}$ inhibitors (Mattson, 1991; Candeo et al., 1992); (2) treatment for $24 \mathrm{hr}$ with phorbol-12-myristate-13-acetic ester that downregulates the expression of PKC in neurons (Favaron et al., 1990); or (3) pretreatment with gangliosides that reduce the duration of the pathologically persistent translocation of PKC from cytosol to the neuronal membrane (Favaron et al., 1988; Manev et al., 1990a,b). Moreover, H7, staurosporine, or gangliosides protect neurons in culture from damage elicited by increased protein phosphorylation induced by okadaic acid, a potent blocker of phosphoprotein phosphatases (Candeo et al., 1992).

The action of gangliosides is of considerable interest because in primary neuronal cultures prepared from newborn rats, either natural gangliosides (GM1, GDla, GT lb) or, more potently and efficiently, two semisynthetic GM1 lysogangliosides (LIGA4 or LIGA20) prevent glutamate neurotoxicity without blocking the glutamate activation of ionotropic or metabotropic receptors (Favaron et al., 1988, 1990; Manev et al., 1990b). This protective effect may be related to the ability of glycosphingolipids to shorten the protracted translocation of PKC and facilitate $\left[\mathrm{Ca}^{2+}\right]$, homeostasis stabilization (Hannun and Bell, 1987; Manev et al., 1989, 1990b; De Erausquin et al., 1990). Although the mechanism whereby PKC affects the regulation of $\left[\mathrm{Ca}^{2+}\right]$, has not yet been identified, it is hypothesized that the PKC-mediated phosphorylation may affect directly or indirectly the function of plasma membrane enzymes, such as $\mathrm{Ca}^{2+}$-dependent ATPase, the $\mathrm{Na}^{+} / \mathrm{Ca}^{2+}$ exchanger and the $\mathrm{Na}+\mathrm{K}^{+}$ATPase, which collectively may participate in the extrusion of $\mathrm{Ca}^{2}:$ from neurons.

The neuroprotective action of the ganglioside GM1 has been documented in several in vivo models of brain ischemia (Greenberg et al., 1987; Karpiak et al., 1990; Leon et al., 1990; Carolei et al., 1991), and although the translocation of PKC to the neuronal membranes has been observed in many of these models (Louis et al., 1988; Joo et al., 1989; Onodera et al., 1989; Cardell et al., 1990; Crumrine et al., 1990; Olah et al., 1990; Zivin et al., 1990; Nabeshima et al., 1991; Ohno et al., 1991; Domanska-Janik and Zalewska, 1992), in only one model, that is, in fetal rat brain after global ischemia, has it been shown that the increase in PKC can be blocked by pretreatment of the pregnant mothers with GMl (Magal et al., 1990). To establish whether the pathologically persistent translocation of PKC in response to excitotoxins play a role in vivo in the area penumbra, we have selected as a model of focal brain ischemia the photochemically induced focal thrombosis of the rat cerebral cortex (Watson et al., 1985; De Ryck, 1990). With this model we provide evidence that in the area penumbra the neurotoxic action of glutamate can be reduced by downregulating PKC with LIGA4 and LIGA20. We have used these semisynthetic GM1 lysoganglioside derivatives instead of the natural ganglioside
GMI for two reasons: (1) we have previously demonstrated that LIGA4 and LIGA20 are more potent, faster-acting, and longerlasting antiexcitotoxic agents than GMl (Manev et al., 1990b), and (2) LIGA4 and LIGA20 penetrate the blood-brain barrier significantly better than the natural gangliosides and are metabolized at a much slower rate (half-life, 2-3 d) (Polo et al., 1992). In the present study, we have compared the action of LIGA4 and LIGA20, both of which do not block glutamate receptors (Manev, 1990b), with that of a selective allosteric antagonist of NMDA-selective glutamate ionotropic receptors such as dizocilpine (MK-801) (Wong et al., 1986; Kemp et al., 1987), as well as an isosteric antagonist of $\alpha$-amino-3-hydroxy-5-methyl4-isoxazolepropionic acid (AMPA) and kainate-selective glutamate ionotropic receptors such as 2,3-dihydroxy-6-nitro-7sulfamoyl-benzo(f)quinoxaline (NBQX) (Sheardown et al., 1990; Honore et al., 1991).

\section{Materials and Methods}

Photochemical-thrombotic Iesion. Male Sprague-Dawley rats weighing $260-300 \mathrm{gm}$ were used throughout these experiments. Our procedure for producing the ischemic lesion is largely based upon that described by Watson et al. (1985) with minor modifications. In brief, rats were deeply anesthetized following intraperitoneal injection of $360 \mathrm{mg} / \mathrm{kg}$ of chloral hydrate (Sigma, St. Louis, MO) and placed securely in a stereotaxic apparatus. Care was taken to position the head directly under the vertically mounted light source. The light source itself consisted of the power supply (single output rated, $15 \mathrm{~V} \mathrm{DC}, 8.4-10.4 \mathrm{~A}$ ), fan, dichroic halogen bulb with parabolic reflector ( $12 \mathrm{~V}, 100 \mathrm{~W}$; wavelength, 400 $1200 \mathrm{~nm}$ with peak energy at $1000 \mathrm{~nm} ; 3400^{\circ} \mathrm{K}$ ), focal lens, and opticial diaphragm. The scalp was retracted and the center of the light was stereotaxically positioned on the exposed flat skull, $1.8 \mathrm{~mm}$ posterior to bregma and $2.8 \mathrm{~mm}$ left of the midline. In this position the underlying brain area corresponds to the left parietal sensorimotor neocortex (Paxinos and Watson, 1982). After injection into the tail vein of the photosensitive dye rose bengal (disodium 4,5,6,7-tetrachloro- $2^{\prime}, 4^{\prime}, 5^{\prime}, 7^{\prime}$-tetraiodofluorescein; Sigma, St. Louis, MO) $(80 \mathrm{mg} / \mathrm{kg})$, the focused light was turned on for $10 \mathrm{~min}$. Following light irradiation animals were left to recover from anesthesia at $37^{\circ} \mathrm{C}$ in a temperature-regulated chamber. Thereafter, the rats were returned to their cages until killed, following survival times of $1,3,6,12$, and $24 \mathrm{hr}$. The lesioned animals could be broadly divided into a nontreated and a treated group, with the latter receiving either antagonists of glutamate receptors MK-801 (Merck, West Point, PA), NBQX (Novo-Nordisk, Malov, Denmark), or the semisynthetic gangliosides LIGA4 and LIGA20 (Fidia, Abano Terme, Italy). In order to evaluate the specificity of the photochemically induced thrombotic ischemia, several control experiments also were performed and consisted of (1) intravenous injection of saline in the absence of rose bengal and then exposing the rats to light for $10 \mathrm{~min}$; (2) intravenous injection of rats with rose bengal but without exposure to the light; (3) injecting rats intravenously with MK-801 $(8.3 \mu \mathrm{mol} / \mathrm{kg})$, LIGA4, or LIGA20 $(35 \mu \mathrm{mol} / \mathrm{kg})$ but in the absence of dye injection or exposure to light; and (4) placing rats in stereotaxic holder but in the absence of drugs, dye injection, or exposure to light.

Tissue preparation. Following appropriate survival times rats were anesthetized with chloral hydrate and killed by cardiac perfusion with $0.9 \%$ saline in $0.05 \mathrm{M}$ phosphate buffer (PB) followed by $4 \%$ buffered paraformaldehyde $(250 \mathrm{ml})$. Alternatively, some rats were not perfused but were killed by exsanguination. In both instances the brains were removed and placed in the fixative for $24-48 \mathrm{hr}$. Following fixation, brains were placed in $30 \%$ buffered sucrose and subsequently sectioned on a sliding microtome to a thickness of $40 \mu \mathrm{m}$. In most instances the brains were sectioned in a coronal plane throughout the rostrocaudal extent of the lesion. Alternatively, some brains were sectioned in a sagittal or horizontal plane. All tissue sections were collected in 24-well culture dishes and stored at $-20^{\circ} \mathrm{C}$ in a cryoprotectant solution consisting of ethylene glycol/glycerol/phosphate buffer.

Autoradiography. Autoradiographic studies using 4- $\beta$-3 $\mathrm{H}$-phorbol12,13-dibutyrate ( ${ }^{3} \mathrm{H}$-PDBu) were carried out as described by Worley et al. (1986) with minor modifications. In brief, free-floating tissue sections adjacent to those used for immunocytochemistry were rinsed $4 \times$ $5 \mathrm{~min}$ in $0.05 \mathrm{M}$ PB. Tissue sections were then incubated for $1 \mathrm{hr}$ at 
$33^{\circ} \mathrm{C}$ in a solution of $50 \mathrm{~mm}$ Tris- $\mathrm{HCl}(\mathrm{pH} 7.7), 100 \mathrm{~mm} \mathrm{NaCl}, 1 \mathrm{~mm}$ $\mathrm{CaCl}_{2}, 0.1 \%$ fatty acid-free bovine serum albumin, and $1,2.5,5,10$, or $20 \mathrm{nM}^{3} \mathrm{H}-\mathrm{PDBu}(18.6 \mathrm{Ci} / \mathrm{mmol}$; New England Nuclear, Boston, MA). Nonspecific binding was assessed by adding $1 \mu \mathrm{M}$ "cold" PDBu to the incubation solution. Following incubation, sections were washed $2 \times 2$ $\mathrm{min}$ in ice-cold $0.05 \mathrm{M} \mathrm{PB}$, rinsed in ice-cold $50 \mathrm{~mm}$ Tris- $\mathrm{HCl}(\mathrm{pH} 7.7)$, mounted onto gelatin-coated glass slides, and dried under a stream of cold air. Autoradiograms were obtained by exposing slides with the labeled tissue to ${ }^{3} \mathrm{H}$-hyperfilm (Amersham) for $7 \mathrm{~d}$ at $4^{\circ} \mathrm{C}$, after which the film was developed. Tritium-calibrated, polymer-coated scales (Amersham Microscales) were exposed in parallel with tissue sections for quantitation. For each animal at least six individual tissue sections were assayed. The autoradiograms were analyzed using an SAMBA4000 computerized imaging system (for detail, see Marlier et al., 1991). The quantitative analysis consisted of the determination of the mean optical density (OD per pixel in a linear $0-255$ range) within a $2-\mathrm{mm}-$ diameter circle that was positioned within the perifocal region of the sensorimotor cortex. Density measurements were compared with measurements within an equal circle positioned within the same region of cortex on the contralateral (i.e., intact) side. Data are represented as the mean of at least 18 measurements (i.e., 3 animals $\times 6$ sections) for each time point. Lesioned and nonlesioned values were compared using a Duncan multiple-range test.

Prior to our data analysis we performed experiments in which wc compared the ability of ${ }^{3} \mathrm{H}-\mathrm{PDBu}$ to bind to $\mathrm{PKC}$ in nonfixed frozen brain tissue versus brain tissue fixed with $4 \%$ paraformaldehyde. Importantly, the degree of resolution was higher in the fixed brain sections; therefore, this procedure was used in all of the experiments reported.

Immunocytochemistry. The avidin-biotin immunocytochemical labeling procedure was adopted from the method of Hsu and Raine (1981) and Armstrong et al. (1987), and consists of the following series of steps: (1) treatment for $30 \mathrm{~min}$ in $0.6 \%$ hydrogen peroxide (nonperfused tissue only); (2) 30 min incubation with $3 \%$ normal rabbit or goat serum diluted in $0.1 \mathrm{M}$ Tris-buffered saline (TBS) containing $0.25 \%$ Triton $\mathrm{X}-100 ;(3)$ overnight incubation with antibodies against c-Fos diluted $1: 2000$ with TBS containing $0.25 \%$ Triton X-100 and $1 \%$ normal serum; (4) incubation for $1 \mathrm{hr}$ with either rabbit anti-sheep or goat anti-rabbit biotinylated secondary IgG diluted 1:200 in TBS containing 1\% normal serum; (5) incubation for $1 \mathrm{hr}$ with avidin biotinylated-peroxidase complex diluted 1:100 with TBS; (6) treatment for 10 min with $0.05 \%$ solution of 3,3'-diaminobenzidine, $0.01 \%$ hydrogen peroxide, and $0.04 \%$ nickel chloride in $0.1 \mathrm{~m}$ Tris buffer. Immunolabeled sections were mounted onto gelatin-coated glass slides, air dried, and covered with Permount and glass coverslips.

Specificity of our immunocytochemical labeling procedure was assessed following substitution of the primary antibody with either nonimmune serum or with M-peptide antigen for c-Fos rabbit antibody. Both procedures resulted in the absence of any peroxidase reaction product. In the present study we employed two polyclonal antibodies against c-Fos. The first consisted of a polyclonal antibody raised in sheep and was obtained commercially from Cambridge Research Biochemicals. This antibody was generated by injecting shecp with the 16 amino acid synthetic c-Fos fragment MFSGFNADYEASSSRC. The peptide was derived from a conserved region of both mouse and human c-Fos and was conjugated to keyholc limpet hemocyanin via the C-terminal cysteine. The second c-Fos antibody was generously provided by Dr. M. J. Iadarola, National Institutes of Health. This polyclonal antibody was raised in rabbits against the synthetic peptide KVEQLSPEEEEKRRIRRIRNKMAAA and was affinity purified against the same antigen (Earnest et al., 1990).

In situ hybridization. Rat $c$-fos riboprobe was labeled with ${ }^{35} \mathrm{~S}-\mathrm{C}$.TP $(>1000 \mathrm{Ci} / \mathrm{mmol}$; Amersham, Arlington Heights, IL) at a specific activity of $2-3 \times 10^{8} \mathrm{cpm} / \mu \mathrm{g}$ for both "sense" and "antisense" probes For details of the transcription reaction, see the protocol provided by Promega. The $c$-fos probe was generously provided by Dr. Dennis Grayson (FGIN, Georgetown University) and represents the 160 nucleotide antisense runoff transcript of the $3^{\prime}$ untranslated region of the mRNA with Sp6 RNA polymerase following linearization with EcoRI. For the in situ hybridization reaction, "free-floating" tissue sections adjacent to those employed for immunocytochemical or autoradiography studics were treated $2 \times 3 \mathrm{~min}$ in $0.1 \mathrm{~m}$ glycine $/ \mathrm{PB} ; 15 \mathrm{~min}$ in Triton X-100/ $\mathrm{PB} ; 30 \mathrm{~min}$ in $1 \mu \mathrm{g} / \mathrm{ml}$ proteinase $\mathrm{K}\left(37^{\circ} \mathrm{C}\right)$; and $5 \mathrm{~min}$ in $4 \%$ paraformaldehyde/PB. Following each step tissue sections were rinsed in 0.1 $\mathrm{M} \mathrm{NaPO}_{4}$ buffer ( $\mathrm{pH} 7.4$ ). Prehybridization was carried out for at least $1 \mathrm{hr}$ at $55^{\circ} \mathrm{C}$ in $1.67 \times \operatorname{SSPE}(1 \times=0.18 \mathrm{M} \mathrm{NaCl} / 10 \mathrm{~mm} \mathrm{NaPO}, \mathrm{pH}$
7.4/1 mM EDTA), 50\% deionized formamide, $1 \times$ Denhart's, $25 \mathrm{~mm}$ dithiothreitol (DTT), 10\% PEG-8000, 0.1\% SDS, and $100 \mu \mathrm{g} / \mathrm{ml}$ denatured sheared herring sperm DNA. Tissue was hybridized for 16-18 hr at $55^{\circ} \mathrm{C}$ in prehybridization solution to which $10 \mu \mathrm{l}$ of denatured probe $\left(4 \mathrm{~min}\right.$ at $95^{\circ} \mathrm{C}$ ) was added to obtain a total volume equal to 0.25 $\mathrm{ml}\left(8-10 \times 10^{\circ} \mathrm{cpm} / \mathrm{section}\right)$. Following hybridization, tissue sections were washed at $55^{\circ} \mathrm{C}$ in $2 \times \operatorname{SSC}(1 \times=0.15 \mathrm{M} \mathrm{NaCl} / 0.015 \mathrm{M} \mathrm{Na}$-citrate, $\mathrm{pH} 7.0$ ) plus $10 \mathrm{~mm}$ DTT for $40 \mathrm{~min} ; 25 \mu \mathrm{g} / \mathrm{ml} \mathrm{RNase} A$ in $0.5 \mathrm{M} \mathrm{NaCl}$ TE (10 mM Tris/1 mM EDTA, pH 8.0) for $40 \mathrm{~min} ; 2 \times$ SSC plus $5 \mathrm{~mm}$ DTT for $2 \times 20 \mathrm{~min}$; and $0.1 \times$ SSC plus $5 \mathrm{~mm}$ DTT for $2 \times 20 \mathrm{~min}$.

Tissue sections were mounted onto glass slides and exposed to DuPont Cronex $4 \mathrm{x}$-ray film for $3 \mathrm{~d}$. After developing the film the slides were dehydrated through graded alcohol, air dried, and dipped in undiluted Kodak NTB-2 photographic emulsion. The slides were developed $10 \mathrm{~d}$ later in D-19 and fixed in F-5 fixative, counterstained for Nissl substance, dehydrated through graded alcohol, coverslipped with DPX mountant, and examined under the light microscope using bright-field optics.

Cytology. Alterations in neuronal density within the area penumbra and the neuroprotective effect of treatment with gangliosides or MK801 were assessed by counting Nissl-stained cells. Stained cells were counted in photomicrographs of a region immediately adjacent to the lesion and in an equivalent brain area in the contralateral (i.e., intact) hemisphere. Each of the photomicrographs were divided evenly into four regions measuring $125 \mu \mathrm{m} \times 300 \mu \mathrm{m}$ and designated region 1,2 , 3 , or 4 such that region 1 was most medial and closest to the lesion and region 4 was most lateral. Within each of these four regions, cell counts were performed by two independent investigators blind to the treatment. The data are expressed as the mean number of cells within a given region. Individual regions were compared within animals and across animal groups using Duncan multiple-range test.

\section{Results}

\section{Autoradiography of ${ }^{3}$ II-PDBu binding}

In brains of sham-operated rats (i.e., receiving rose bengal under chloral hydrate anesthesia but no irradiation with light) the distribution of ${ }^{3} \mathrm{H}-\mathrm{PDBu}$ binding - a ligand for PKC (Worley et al., 1986)-is heterogeneous with the highest density occurring in the CA1 and CA3 subfields of the hippocampus; next highest in the cerebral cortex, particularly within the enthorinal cortex; followed by a relatively low density in the hippocampal dentate gyrus (Fig. $1 A$ ). ${ }^{3} \mathrm{H}$-PDBu binding is barely detectable in the diencephalon and virtually absent in the cerebellum (data not shown). MK-801 ( $8.3 \mu \mathrm{mol} / \mathrm{kg}$, i.v.), injected $4 \mathrm{hr}$ prior to death, decreases the overall intensity of ${ }^{3} \mathrm{H}$-PDBu binding throughout all brain regions including the hippocampus (Fig. $1 B$ ). The distribution of ${ }^{3} \mathrm{H}-\mathrm{PDBu}$ binding is virtually identical in the brains of the sham-operated and normal rats.

In the brains of animals with a unilateral photochemicalthrombotic lesion in the sensorimotor parietal cortex, ${ }^{3} \mathrm{H}-\mathrm{PDBu}$ binding is maximally increased in the perifocal area (Fig. 1C) and to a lesser extent throughout much of the cerebral hemispheres ipsilateral and contralateral to the lesion, including the cingulate cortex, enthorinal cortex, and hippocampus (Fig. 1C). The intensity of ${ }^{3} \mathrm{H}-\mathrm{PDBu}$ binding in the perifocal area is maximum $3 \mathrm{hr}$ after the photochemical lesion and thereafter slowly declines toward basal values (Fig. 2). In all brain areas ${ }^{3} \mathrm{H}-\mathrm{PDBu}$ binding can be abolished by incubating the tissue slices with an excess of cold PDBu.

In order to determine whether the increase in binding in the lesioned brain reflected alterations in the affinity, or rather changes in the number of PDBu binding sites, we incubated coronal brain sections with $1,2.5,10$, and $20 \mathrm{~nm}{ }^{3} \mathrm{H}-\mathrm{PDBu}$. The lower concentrations (i.e., 1 and $2.5 \mathrm{nM}$ ) were selected because they were close to the apparent $K_{d}$ value of ${ }^{3} \mathrm{H}-\mathrm{PDBu}$ to its receptor in tissue, whereas the higher concentrations (i.e., 10 and $20 \mathrm{nM}$ ) more closely approximated saturating concentra- 


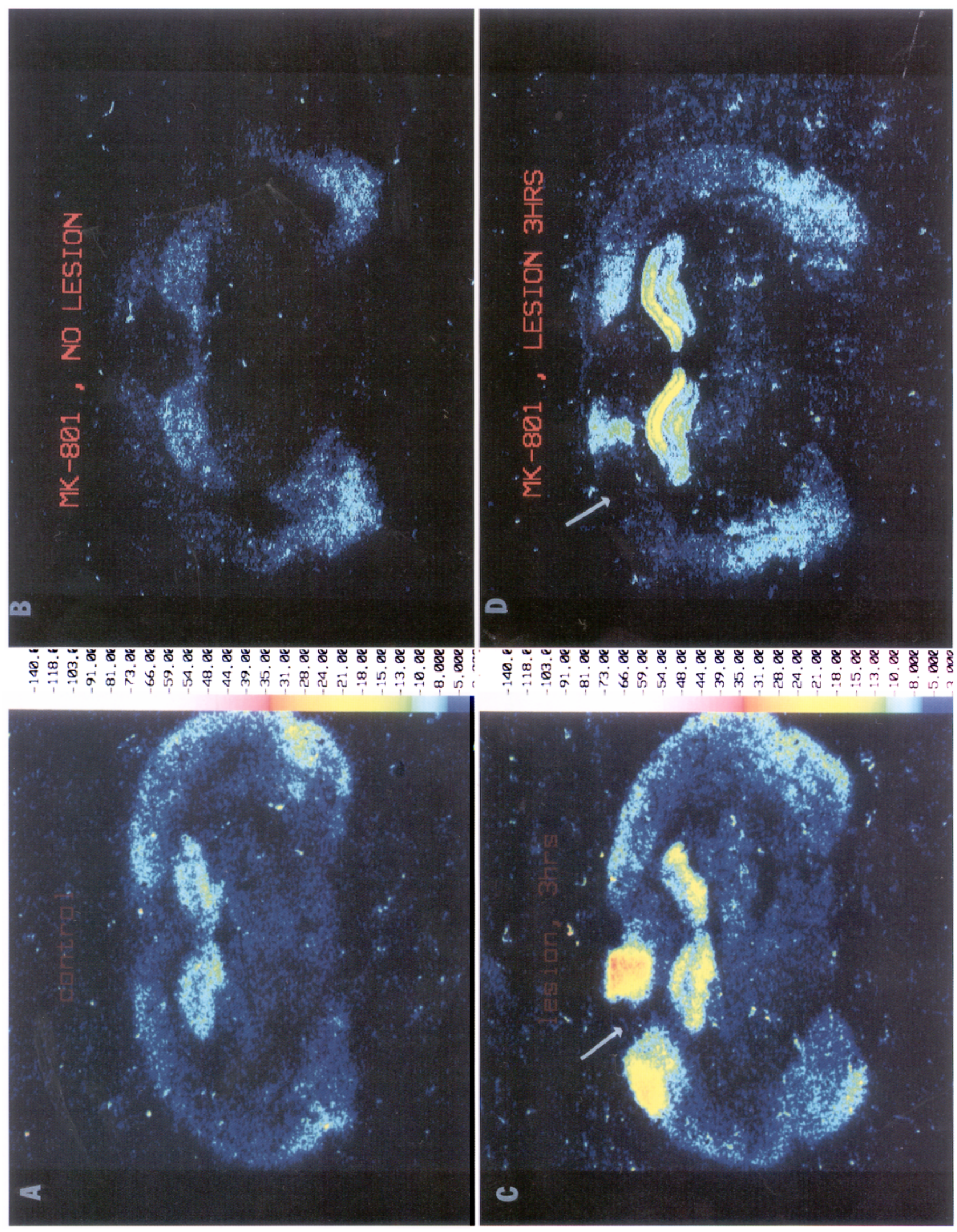




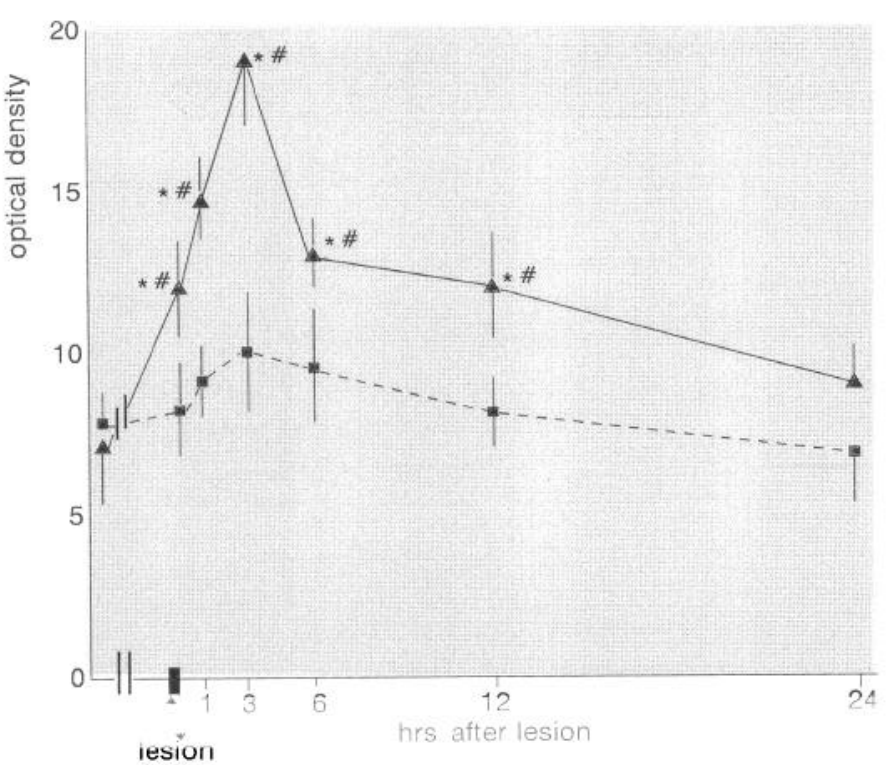

Figure 2. Time-dependent changes in the density of ${ }^{3} \mathrm{H}-\mathrm{PDBu}$ binding in a region of the cingulate cortex adjacent to the infarcted zone and in a comparable region in the contralateral (i.e., nonlesioned) cingulate cortex. For the quantitative analysis, optical densities of color-coded images were analyzed as described in Materials and Methods. The lesion is located in the parietal cortex as indicated in Figure 1. Solid line indicates changes of ${ }^{3} \mathrm{H}-\mathrm{PDBu}$ binding in the cingulate cortex adjacent to the infarcted area ipsilateral to the lesion. Dashed line indicates changes of ${ }^{3} \mathrm{H}-\mathrm{PDBu}$ binding in the corresponding cingulate cortex contralateral to the lesion. Each point represents the mean \pm SEM of six to eight animals. Arrows indicate start and finish of the light illumination (10 $\min ){ }^{*}, p<0.05$ when compared with control group (brains without lesion); $\#, p<0.05$ when the side ipsilateral to the lesion was compared with the contralateral side.

tions for the binding sites (Worley et al., 1986). Despite an increase in the overall background level of binding, the higher concentrations of tritiated ligand yields no difference in the relative increase in ${ }^{3} \mathrm{H}-\mathrm{PDBu}$ binding compared to brain incubated with 1 or $2.5 \mathrm{nM}^{3} \mathrm{H}-\mathrm{PDBu}$. These results suggest that in the lesioned animals the increased binding likely reflects an increase in the density $\left(B_{\max }\right)$ and not in the affinity $\left(K_{d}\right)$ for the radiolabeled ligand.

Following pretreatment with MK- $801(8.3 \mu \mathrm{mol} / \mathrm{kg}$, i.v., $1 \mathrm{hr}$ prior to the lesion), the increase of ${ }^{3} \mathrm{H}-\mathrm{PDBu}$ binding in the perifocal area and in the dentate gyrus of the hippocampus is considerably reduced (Fig. 1D). The MK-801-mediated inhibition of the increase in ${ }^{3} \mathrm{H}-\mathrm{PDBu}$ binding in the perifocal area lasts less than 5-7 hr, after which the ${ }^{3} \mathrm{H}-\mathrm{PDBu}$ binding in the perifocal area rises to an intensity comparable to that observed in rats with photochemical lesion but untreated with MK-801. The increase of ${ }^{3} \mathrm{H}-\mathrm{PDBu}$ binding within the perifocal area also is reduced in rats pretreated $1 \mathrm{hr}$ prior to surgery with $35 \mu \mathrm{mol} /$ $\mathrm{kg}$ (i.v.) of LIGA4 or LIGA20, or $89.2 \mu \mathrm{mol} / \mathrm{kg}$ of the nonNMDA glutamate receptor antagonist NBQX (Fig. 3). The data with MK-801 and NBQX indicate that at least in the perifocal

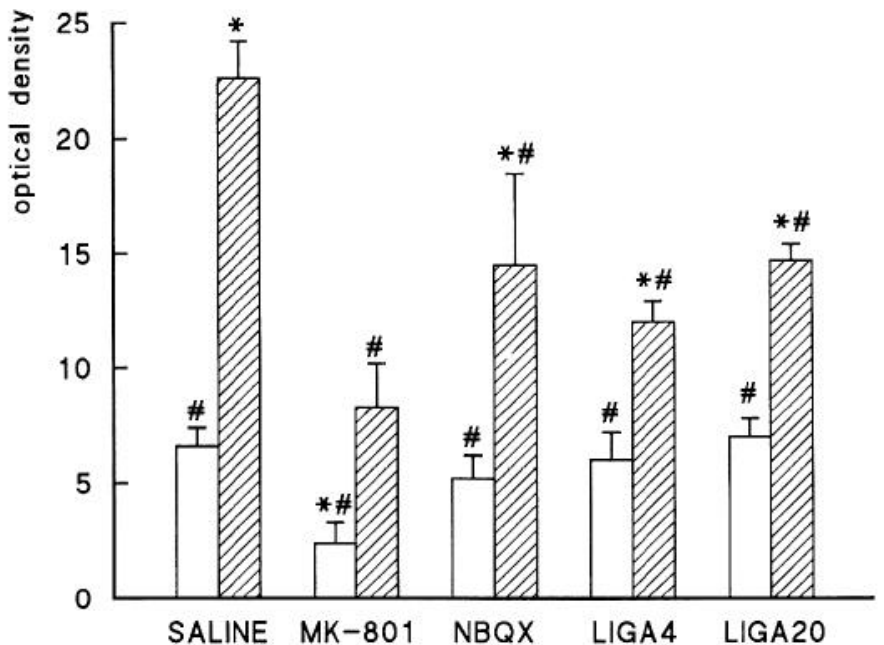

Figure 3. MK-801, NBQX, LIGA4, and LIGA20 reduce the increase of ${ }^{3} \mathrm{H}-\mathrm{PDBu}$ binding in the cingulate cortex adjacent to the infarcted zone (hatched bars). The lesion is located in the left parietal cortex as indicated in Figure 1. MK-801 but not NBQX, LIGA4, and LIGA20 decrease ${ }^{3} \mathrm{H}-\mathrm{PDBu}$ binding in cingulate cortex of sham-operated rats (open bars). Optical density was calculated as described in Materials and Methods. ${ }^{*}, p<0.05$ ' when compared with the sham-operated group treated with saline; $\#, p<0.05$ when compared with the lesioned group treated with saline.

area the rise in ${ }^{3} \mathrm{H}-\mathrm{PDBu}$ binding is linked to the overstimulation of NMDA- and non-NMDA-selective glutamate receptors and is mediated by an excess of free glutamate in the interstitial fluid. Since LIGA20 and LIGA4, injected in shamoperated rats, fail to change the basal ${ }^{3} \mathrm{H}-\mathrm{PDBu}$ binding (Fig. 3 ), and fail to inhibit glutamate channel gating of NMDA- and non-NMDA-glutamate ionotropic receptor families (Manev et al., 1990b), one has to assume that the inhibition of (the expectant increase) ${ }^{3} \mathrm{H}$-PDBu binding elicited by these two semisynthetic lysogangliosides is due to an action on specific processes resulting from the paroxysmal and continuous stimulation of receptors by the glutamate present in high concentrations in extraneuronal fluids.

\section{c-fos $m R N A$ and c-Fos-like immunoreactivity}

Following the focal photochemical-thrombotic lesion we observed a marked increase in c-Fos-like immunoreactivity (cFos-Li) as well as c-fos mRNA throughout the entire cortex ipsilateral to the lesion (Figs. 4, 5). The increase in c-Fos-Li is evident within $1 \mathrm{hr}$ after the lesion, peaks at 3-6 hr postlesion, begins to decline $12 \mathrm{hr}$ postlesion, and by $24 \mathrm{hr}$ following the lesion is barely detectable. c-Fos- $\mathrm{Li}$ is observed within most cortical layers with the exception of layer I and within the pyramidal neurons of layer $\mathrm{V}$ where it is conspicuously absent. Importantly, c-Fos- $\mathrm{Li}$ is distributed throughout all regions of the cortex ipsilateral to the lesion with particularly high concentrations within the enthorinal and pyriform cortices and is not observed in the hippocampus, basal ganglia, thalamus, hy-

\footnotetext{
Figure 1. MK-801 blocks the photochemical-thrombotic lesion-induced increase of ${ }^{3} \mathrm{H}-\mathrm{PDBu}$ binding in the left parietal cortical hemisphere (sensorimotor area) of rat brain: computer-generated color-coded images of ${ }^{3} \mathrm{H}-\mathrm{PDBu}$ binding distribution. Color bar shows the calibration (optical density) of ${ }^{3} \mathrm{H}$-PDBu binding for these images. $A$, Coronal section at the level of dorsal hippocampus of sham-operated rats. $B$, Sham-operated rats treated with MK-801 $(8.3 \mu \mathrm{mol} / \mathrm{kg}$, i.v., $4 \mathrm{hr}$ before death). $C$, Section $3 \mathrm{hr}$ after unilateral photochemical-thrombotic lesion; arrow indicates infarcted area. $D$, Same as $C$ but rats were pretreated with MK-801 $(8.3 \mu \mathrm{mol} / \mathrm{kg}$, i.v., $4 \mathrm{hr}$ before death, $1 \mathrm{hr}$ before lesion).
} 

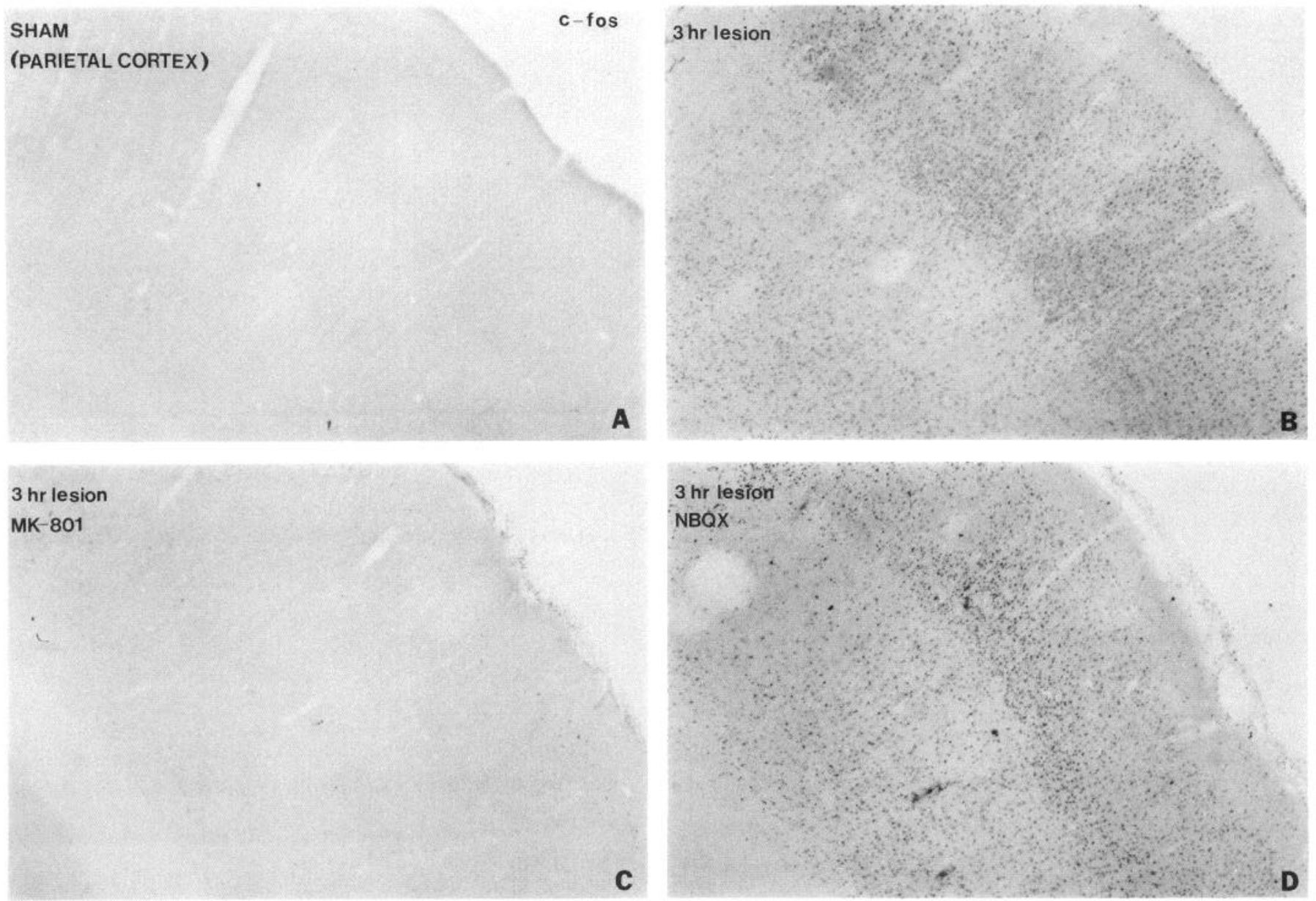

Figure 4. Effect of MK-801 and NBQX on the increase of c-Fos-like immunoreactivity in the cortical hemisphere ipsilateral to the site of the photochemical-induced lesion. Photomicrographs from the area of parietal cortex adjacent to the infarcted zone $3 \mathrm{hr}$ after the lesion $(B-D)$ or from the corresponding area of parietal cortex of sham-operated animals $(A) . A$, In sham-operated rats virtually no c-Fos-Li was observed. $B$, Following ischemic insult c-Fos-Li was dramatically increased. $C$, c-Fos-Li was inhibited in rats receiving MK- $801(8.3 \mu \mathrm{mol} / \mathrm{kg}$, i.v., $4 \mathrm{hr}$ before death). $D$, In contrast, rats receiving NBQX $(89.2 \mu \mathrm{mol} / \mathrm{kg}$, i.v., $4 \mathrm{hr}$ before death) displayed a small reduction in c-Fos- $\mathrm{Li}$.

pothalamus, or cerebellum. c-Fos- $\mathrm{Li}$ is also conspicuously absent from the infarcted area itself. The widespread distribution of c-Fos-Li throughout the ipsilateral cortex is particularly apparent in sagittal and horizontal sections where c-Fos-Li can be observed extending from the frontal to the occipital poles of the brain. Similarly, the photochemical lesion induces a marked rise in $c$-fos mRNA throughout the ipsilateral cortex in a manner that parallels the expression of the protein (Fig. 5). In contrast, in the contralateral (i.e., nonlesioned) cortex $c$-fos mRNA and c-Fos-Li are expressed with relatively low intensity and do not appear at any time to differ from the basal levels observed in nonlesioned control animals.

The increase of c-Fos-Li as well as c-fos mRNA is substantially blocked following pretreatment of rats with MK-801 (8.3 $\mu \mathrm{mol} / \mathrm{kg}$, i.v.) (Figs. $4 C, 5 B)$. In contrast, NBQX, even when administered in large doses $(89.2 \mu \mathrm{mol} / \mathrm{kg}$, i.v.), marginally prevents the rise in c-Fos- $\mathrm{Li}$ and virtually fails to block $c$-fos mRNA expression (Figs. 4D, 5C). The blocking effect of MK-801, however, is transient, and following a single intravenous injection of the drug, the expression of c-Fos- $\mathrm{Li}$ is suppressed for only 5-7 hr after which the protein is once again elevated throughout the ipsilateral (i.e., lesioned) cortex. Importantly, a second administration of MK-801, $4 \mathrm{hr}$ following the initial injection, helps to maintain c-Fos-Li at near-basal levels even several hours following the lesion. Interestingly, MK-801 induces a slight increase of c-Fos- $\mathrm{Li}$ in the contralateral (i.e., nonlesioned) cortex. In contrast, when rats were treated with LIGA4 and LIGA20, in doses that are known to reduce the lesion-induced rise of ${ }^{3} \mathrm{H}$ PDBu binding, the increased expression of $c$-fos mRNA (Fig. 5 ) or c-Fos-Li (not shown) is not suppressed. In control experiments, c-Fos-Li content is not increased by the chloral hydrate anesthesia, or following rose bengal administration in the absence of irradiation, or following administration of LIGA4 or LIGA20 in the absence of any further treatment.

\section{Cytological changes}

In Nissl-stained tissue sections we analyzed the cytological changes occurring in the area penumbra adjacent to the infarcted area $3 \mathrm{hr}$ after the lesion. The infarcted area, which is parabolic in shape and approximately $3 \mathrm{~mm}$ in diameter, is characterized in Nissl-stained sections by complete neuronal loss and evidence of several pial and parenchymal thrombotic vessels (Fig. 6C). In contrast, the cortical regions adjacent to the infarct (i.e., penumbra areas) do not contain thrombotic vessels, yet display a reduction in the number of Nissl-stained neurons. Moreover, many of the remaining neurons in the area penumbra appear 


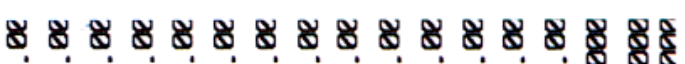

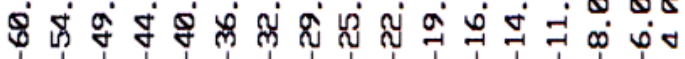
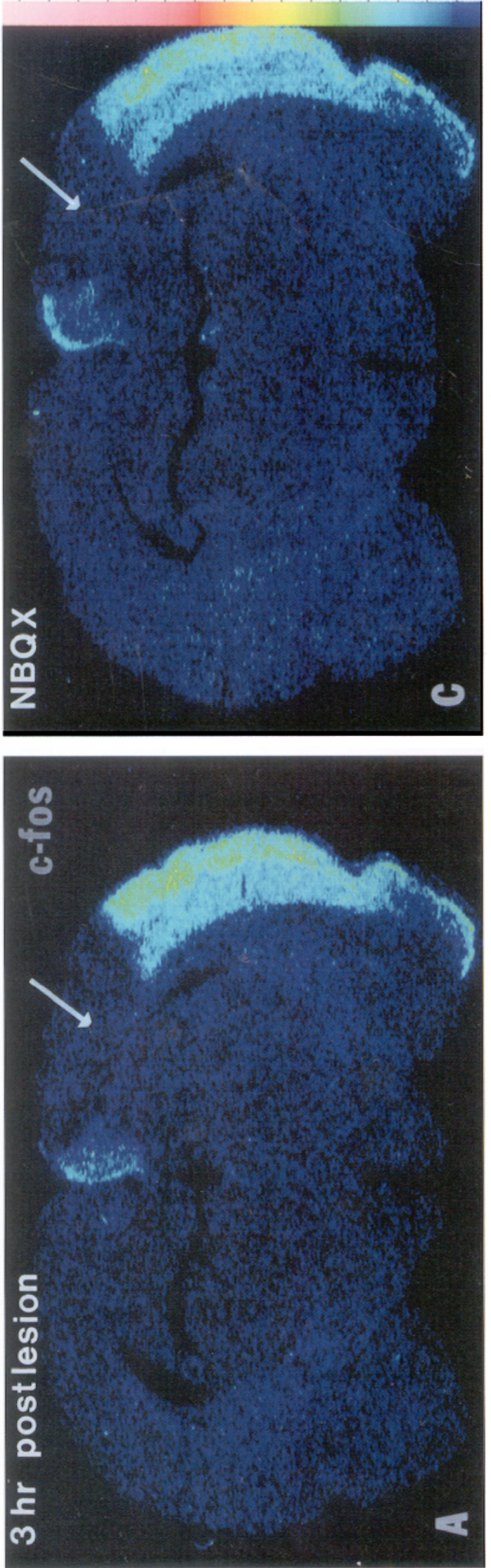
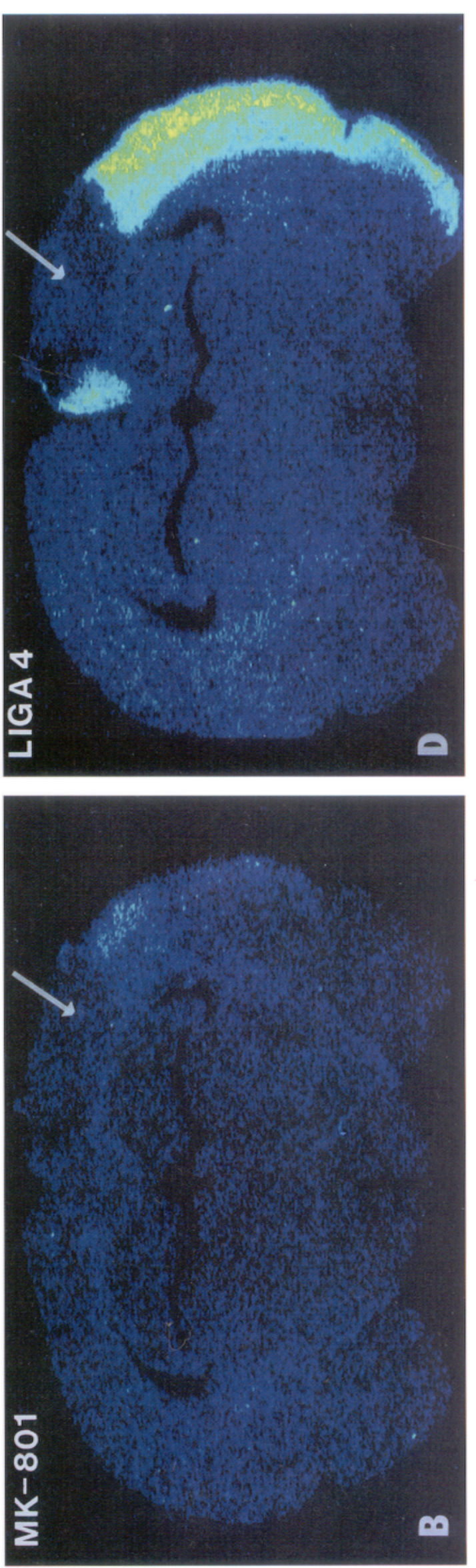

s்

密察

융

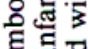

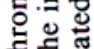

政

政

हi.

政.

敦识

这类

范

흥.응

कू

o 区 ख

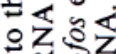

ozio

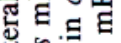

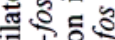

क्.

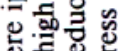

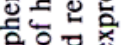

을

․․요

ब은

웅ㅎㅁ

응

ํㅡ은

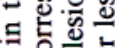

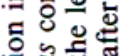

है

氮气

정

×

\5.

ํㅗ월

좋

s. 항.

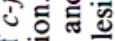

吠

论

넝 흥

死焉

은ㄹ

드는

ํํ으ำ

एँ

능궁

ن⿺辶⿻日禸

乙二

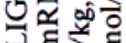

등

○气ำ

Oु-

Z $\infty$

영므

ㅌ․

吉资造

원

원

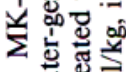

吼 를

น है

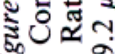

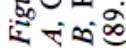




\author{
3hr post-lesion / contra
}
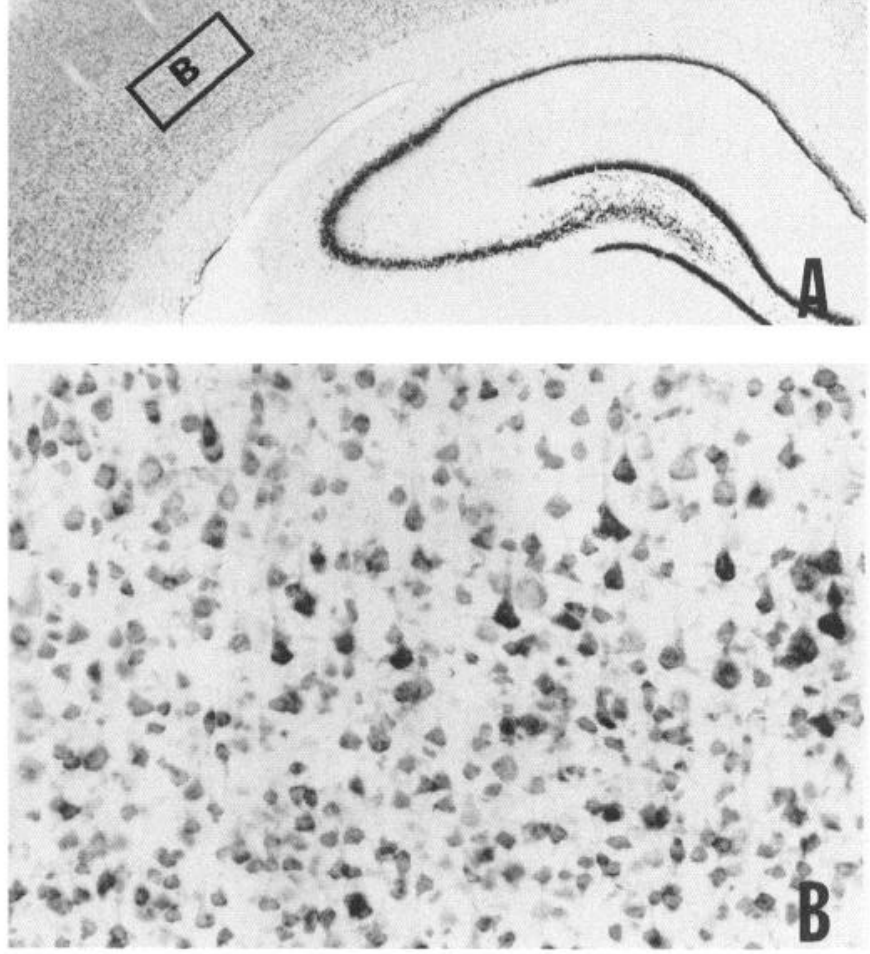

ipsi

$1 \mathrm{~mm}$
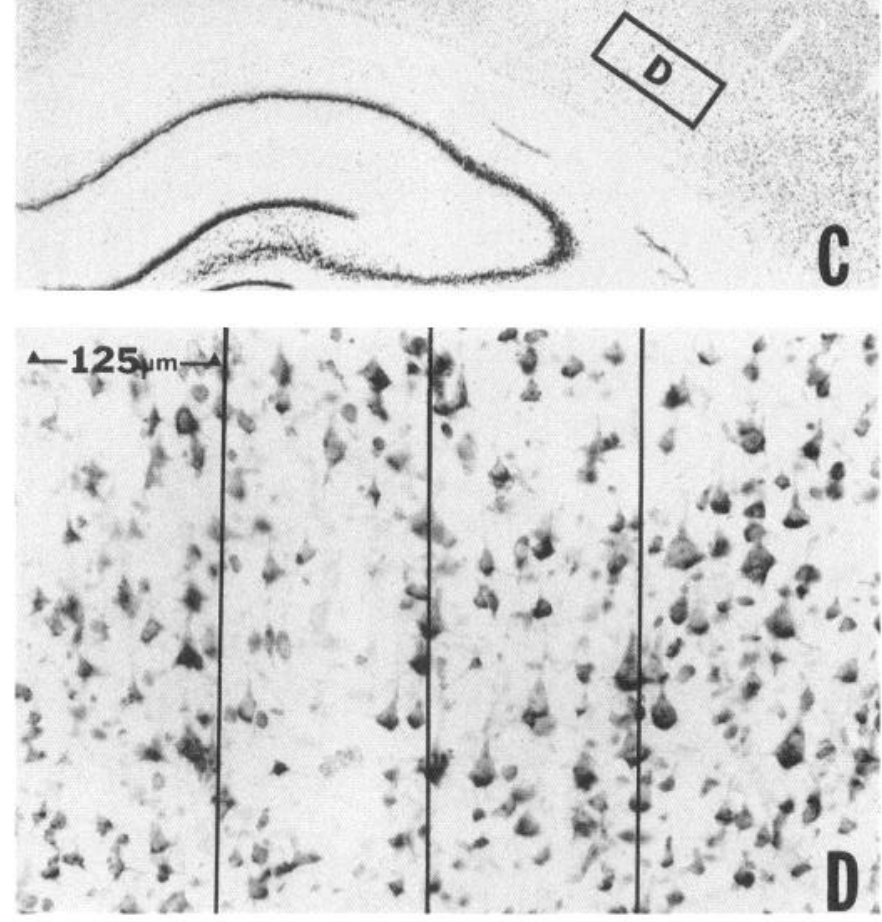

Figure 6. Photomicrographs of Nissl-stained coronal brain hemisections of rats killed $3 \mathrm{hr}$ after lesion, demonstrating evidence of neuronal death in the penumbra area adjacent to the focal infarcted area. $A$ and $B$, Photomicrographs showing low- $(A)$ and high- $(B)$ power magnifications of Nissl-stained tissue section, contralateral to the infarct. $C$ and $D$, Low- $(C)$ and high- $(D)$ power photomicrographs of Nissl-stained tissue section of infarcted parietal cortex. The infarcted area appears pale. Box $B$ in photomicrograph $A$ and box $D$ in photomicrograph $C$ correspond to the higher-magnification photomicrographs $B$ and $D$. Cell counts were obtained from an area immediately adjacent to the periinfarcted area that corresponds largely to layer $\mathrm{V}($ box $D)$. This region, for purposes of cell counting, was divided into four zones, each measuring $0.125 \mathrm{~mm} \times 0.300$ $\mathrm{mm}$. Neuronal loss was most evident in the more medial regions. Statistical analysis of seven experiments in which the number of Nissl-positive cells is counted in the penumbra area and in the contralateral side is reported in Table 1.

either swollen or present with a distorted profile (Fig. 6D). When MK- 801 is administered $1 \mathrm{hr}$ before the lesion, it reduces the loss of Nissl-stained neurons in the penumbra area when examined $3 \mathrm{hr}$ after the lesion (Table 1). In the present study quantitative analysis was restricted to layer $\mathrm{V}$ neurons, but our qualitative impression suggested that the neuroprotective action of MK-801 likely extends beyond this region and includes all cortical layers. Although the neuronal damage and neuronal loss appear to progress for at least $24 \mathrm{hr}$ following the lesion, resulting in marked disorganization of the cortical cytoarchitectonics in the area penumbra, we have selected to measure the protective action of MK- 801 at $3 \mathrm{hr}$ after the lesion largely because of the short half-life of MK-801 (3-4 hr), which prevents accurate assessment of the neuroprotective action of this compound at later times (i.e., 12 or $24 \mathrm{hr}$ ). Importantly, LIGA4 $(35 \mu \mathrm{mol} /$ $\mathrm{kg}$, i.v., injected $1 \mathrm{hr}$ before lesion), although ineffective in reducing the size of the infarcted area, protects Nissl-positive neurons in layer $\mathrm{V}$ of the perifocal cortical area against loss and damage (Fig. $7 D$, Table 1). Although the neuroprotective actions of MK-801 and LIGA4 were observed throughout all regions assayed, the effect was most dramatic in regions most proximal to the lesion, reflecting in part the pronounced cell loss within these regions of saline-treated rats (Table 1). Results similar to those obtained with LIGA4 were obtained by administering an equimolar amount of LIGA20 (data not shown). The protection afforded by administration of LIGA4 and LIGA20, contrary to that of MK-801, is still evident $24 \mathrm{hr}$ after the lesion.

\section{Discussion}

In the present study, we produced a focal ischemic lesion in the sensorimotor cortex of rat to be used as a model of microthrombotic brain infarct. The infarct was induced by photochemicalthrombotic occlusion of the intrinsic vessels of this region (Watson and Dietrich, 1990). In the lesioned sensorimotor cortex area, one can recognize two regions: (1) the infarcted core characterized by thrombotic vessels and widespread neuronal death, the latter presumably due to an insufficient blood supply; and (2) the penumbra area, which receives some blood supply from nonoccluded vessels but where edema (Astrup et al., 1981; Pierpaoli et al., 1992), reduced blood flow (Dietrich et al., 1987) 


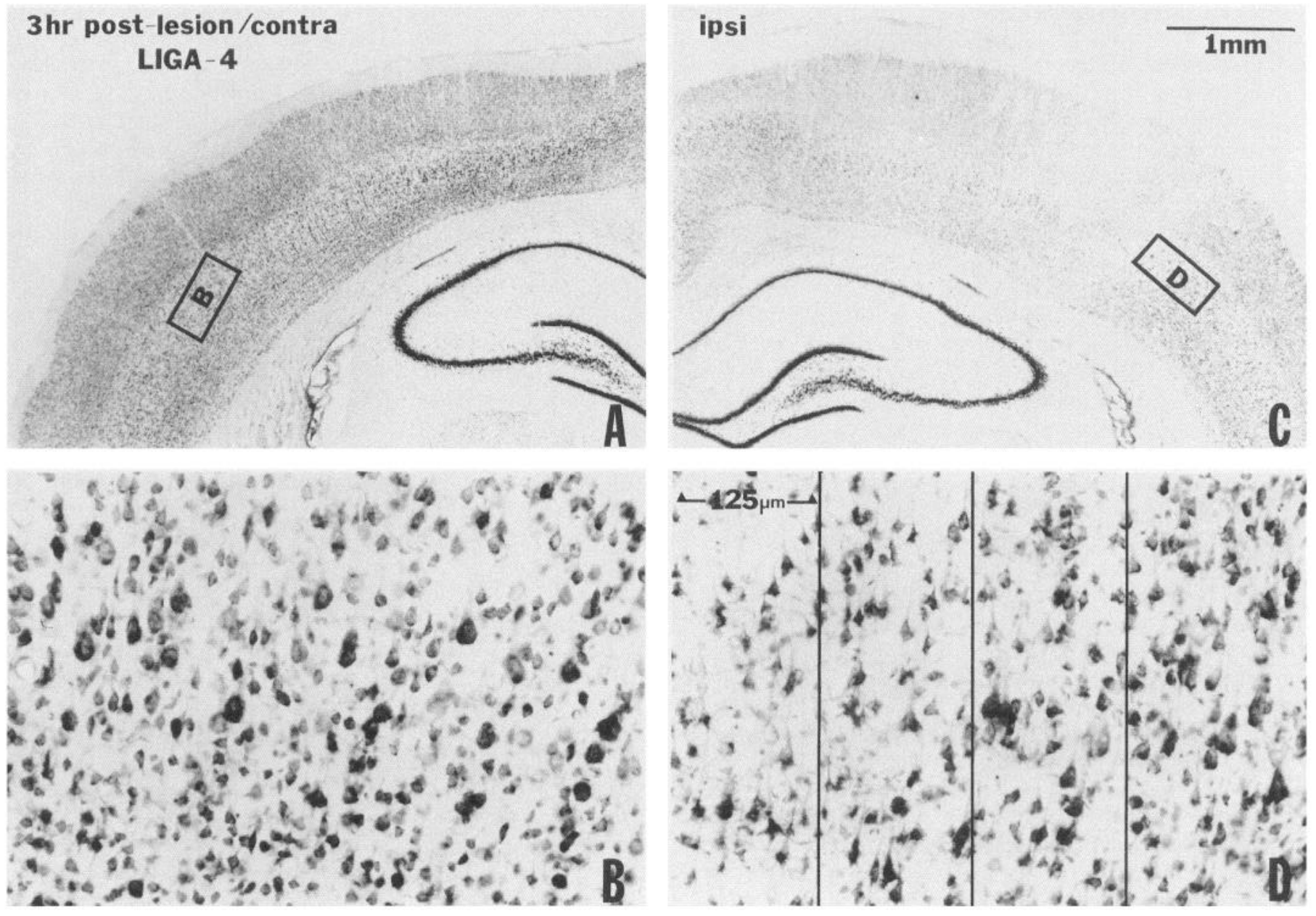

Figure 7. LIGA4 $(35 \mu \mathrm{mol} / \mathrm{kg}$, i.v.) provided neuroprotection in the penumbra area adjacent to the lesion. The experimental conditions and the presentation of the results are identical to that of Figure 6 . LIGA4 was injected $1 \mathrm{hr}$ before the lesion. Although cells are reduced compared to the contralateral side, the LIGA4-treated animals, nevertheless, display considerable neuroprotection compared to the nontreated rats (compare Figs. $6 D, 7 D$ ). Statistical analysis of seven experiments in which the number of Nissl-positive cells is counted in the penumbra area and in the contralateral side is reported in Table 1.

and, as proposed here, increased glutamate content in the interstitial fluid may collectively contribute to neuronal damage and probably death.

An assessment of neuronal damage in the penumbra area was established by counting Nissl-positive neurons in the cortical region adjacent to the infarcted area and comparing neuronal density to that found in an identical cortical region in the contralateral hemisphere. In untreated rats the neuronal damage in the penumbra area was already impressive $3 \mathrm{hr}$ after the termination of the lesion, and yet it continued to evolve until 24 hr when this region was characterized by irreversible alterations in cortical cytoarchitecture. The extent of this damage was decreased by pretreating rats with the NMDA-specific glutamate receptor antagonist $\mathrm{MK}-801$ (Table 1).

The neuronal damage in the area penumbra is paralleled by a dramatic increase of ${ }^{3} \mathrm{H}$-PDBu binding, which peaks $3 \mathrm{hr}$ after the lesion (Fig. 2). This increase does not occur in the infarcted zone, yet is maximal in the penumbra area, and unlike the increase of $c$-fos or c-Fos- $\mathrm{Li}$, which is observed throughout the cortex ipsilateral to the lesion, the rise in ${ }^{3} \mathrm{H}-\mathrm{PDBu}$ is marginal

\section{Table 1. MK-801 and LIGA4 reduce the cell loss in the penumbra area}

\begin{tabular}{|c|c|c|c|c|c|c|c|c|c|c|}
\hline \multirow{2}{*}{$\begin{array}{l}\text { Treatment } \\
(\mu \mathrm{mol} / \mathrm{kg}, \mathrm{i} . \mathrm{v} .)\end{array}$} & \multicolumn{5}{|c|}{ Ipsilateral to the lesion } & \multicolumn{5}{|c|}{ Contralateral to the lesion } \\
\hline & Total & Zone 1 & Zone 2 & Zone 3 & Zone 4 & Total & Zone 1 & Zone 2 & Zone 3 & Zone 4 \\
\hline Saline & $215 \pm 8.0$ & $14 \pm 1.0$ & $18 \pm 1.1$ & $19 \pm 1.0$ & $21 \pm 1.0$ & $311 \pm 12^{*}$ & $25 \pm 1.2^{*}$ & $27 \pm 1.2^{*}$ & $26 \pm 1.1^{*}$ & $25 \pm 1.3^{*}$ \\
\hline MK-801 (8.3) & $330 \pm 10^{*}$ & $21 \pm 1.2^{*}$ & $26 \pm 1.0^{*}$ & $27 \pm 1.3^{*}$ & $31 \pm 1.0^{*}$ & $345 \pm 13^{*}$ & $30 \pm 1.6^{*}$ & $33 \pm 1.4^{*}$ & $32 \pm 1.2^{*}$ & $33 \pm 1.5^{*}$ \\
\hline LIGA4 (35.0) & $297 \pm 14^{*}$ & $22 \pm 1.6^{*}$ & $24 \pm 1.3^{*}$ & $26 \pm 1.1^{*}$ & $27 \pm 1.1^{*}$ & $333 \pm 10^{*}$ & $27 \pm 1.2^{*}$ & $29 \pm 1.3^{*}$ & $28 \pm 1.0^{*}$ & $27 \pm 1.0^{*}$ \\
\hline
\end{tabular}

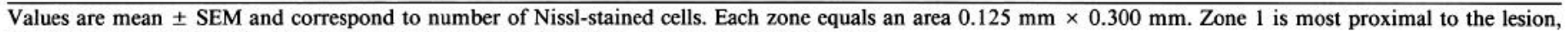
while Zone 4 is most distal. Total area equals the sum of four (i.e, $0.500 \mathrm{~mm} \times 0.300 \mathrm{~mm}$ ).

${ }^{*} p<0.05$ when compared with lesioned side of saline-treated group within the same region. 
in the cortical regions distal to the lesion (compare Figs. 1, 5). A single administration of either MK-801 or NBQX, 1 hr before the lesion, reduces the increase of ${ }^{3} \mathrm{H}-\mathrm{PDBu}$ binding for a period of approximately $6 \mathrm{hr}$ (Fig. 3). Thus, the protection from neuronal loss and the reduction of the increase of ${ }^{3} \mathrm{H}-\mathrm{PDBu}$ binding observed during the first $3 \mathrm{hr}$ in the area penumbra of rats pretreated with MK-801 or NBQX suggest that high levels of glutamate in the interstitial fluids are a major factor contributing to the increase of ${ }^{3} \mathrm{H}-\mathrm{PDBu}$ binding and to the neuronal damage in this area.

$\mathrm{PDBu}$ is a phorbol ester with high affinity (nM) for various PKC isoenzymes and is known to be a selective ligand and a potent activator for the regulatory subunit of these isoenzymes (Worley et al., 1986; Nishizuka et al., 1991). Following glutamate receptor stimulation of primary cultures of rat cerebellar and cerebral cortical neurons, changes in the number of binding sites for ${ }^{3} \mathrm{H}-\mathrm{PDBu}$ werc associated with activation and translocation of PKC molecules from the cytosol to the neuronal membrane (Favaron et al., 1990; Manev et al., 1990a). Similarly, following brain ischemia in rat and gerbil, changes in PDBu binding have been positively correlated with the translocation of PKC from the cytosol to the neuronal membranes (Onodera et al., 1989; Cardell et al., 1990; Zivin et al., 1990; Domanska-Janik and Zalewska, 1992). It is therefore possible to infer that an increase of ${ }^{3} \mathrm{H}$-PDBu binding observed in the area penumbra in our focal ischemic model likely reflects a glutamate-induced increase in PKC catalytic activity due to activation and translocation of the enzyme from the cytosol to the neuronal membrane.

The translocation of cytosolic PKC to neuronal membranes following physiological intermittent glutamate receptor stimulation is generally a fast, reversible process but it can become a slowly reversible event in the case of pathological and persistent stimulation of glutamate receptors (Manev et al., 1990a; Mattson, 1991). Thus, under the latter conditions the pathological translocation of PKC may result in an abnormal phosphorylation of various neuronal proteins operative in $\left[\mathrm{Ca}^{2+}\right]$, extrusion and therefore can be an important factor in destabilizing $\left[\mathrm{Ca}^{2+}\right]$, homeostasis. A consequence of a destabilized $\left[\mathrm{Ca}^{2}+\right]$, homeostasis is the accumulation of high levels of free $\left[\mathrm{Ca}^{2+}\right]$, which in turn may activate neuronal proteases and lipases or activate neuronal free radical formation and induce ncuronal damage and neuronal death (Manev et al., 1990a; Mattson, 1991).

Importantly, in vitro studies demonstrate that both natural gangliosides (GM1, GT1B) and the semisynthetic lysoganglioside derivatives of GM 1 (LIGA4 and LIGA20) reduce the protracted destabilization of $\left[\mathrm{Ca}^{2+}\right]$, homeostasis and the protracted and massive translocation of PKC to the ncuronal membranes, both elicited by abusive stimulation of glutamate receptors (Manev et al., 1990a,b). Gangliosides and the semisynthetic lysogangliosides perform this action without blocking the glutamate ionotropic or metabotropic receptor function and the glutamateinduced expression of IEG (Manev et al., 1990a,b). Although the precise mechanism by which natural gangliosides and the semisynthetic lysoganglioside derivatives of GM 1 produce their neuroprotective effect is unclear, it is thought that the action of gangliosides depends on their ability to reduce the pathological PKC-dependent phosphorylation of membrane proteins operative in $\left[\mathrm{Ca}^{2+}\right]$, homeostasis regulation.

Pretreatment of pregnant rodents with the natural ganglioside GM 1 prevents the protracted, pathological translocation of PKC induced in the brain of fetal rats after global ischemia (Magal et al., 1990). Recently GM1 has been reported to reverse the increased levels of $\mathrm{PKC}$ induced in rat spinal cord by peripheral nerve injury (Mao et al., 1992). In line with these data, we have demonstrated in vivo a long-lasting reduction in the increase of ${ }^{3} \mathrm{H}$-PDBu binding in the area penumbra, when LIGA4 and LIGA 20 are given before the photochemical-thrombotic lesion. The pretreatment with LIGA4 and LIGA20 allows these semisynthetic lysoganglioside derivatives of GMl to insert in the neuronal membranes, where they are slowly metabolized, the metabolism of LIGA20 having a half-life of 2-3 d (Polo et al., 1992). However, unlike MK-801, LIGA4 and LIGA20 do not reduce the glutamate-mediated elevation of $c$-fos expression and c-Fos-Li (see Figs. 4, 5). The latter occurs maximally in cerebral cortical areas ipsilateral to the focal lesion, including areas where there is virtually no cytological evidence of neuronal death or damage, and is paralleled by concurrent large increases of jun$B$, 7if/269, and nur/77 expression (R. Hayes, unpublished observations). Thus, these data support the concept that the induction of IEG expression is a nontoxic immediate response to glutamate receptor stimulation. Moreover, that LIGA4 and LIGA20 fail to reduce the lesion-induced increase in IEG expression indicates that gangliosides do not block the glutamate gating of ionotropic receptors, thus leaving intact glutamatergic transmission in brain areas that are not affected by pathology.

The evidence that gangliosides fail to block the glutamateinduced increase in IEG expression as well as fail to prevent the MK-801-sensitive increase of BDNF in the cortical hemisphere ipsilateral to the photochemical-thrombotic lesion (Comelli et al., 1992) corroborates the hypothesis that the proteins expressed by IEG activation are unrelated to the cascade of biochemical interactions participating in glutamate-induced neuronal death; rather, they may act as nuclear third messengers initiating the expression of molecular processes (i.e., BDNF) operative in neurotrophic or neuroplastic events.

Collectively, the protective action of MK-801 on neuronal loss and in suppressing the incrcase of ${ }^{3} \mathrm{H}-\mathrm{PDBu}$ strongly suggests that in this brain lesion model, glutamate is released in excess and for several hours into the interstitial space within the area penumbra adjacent to the infarcted area. It is important to note that glutamate may act on neurons by translocating PKC and by destabilizing $\left[\mathrm{Ca}^{2} \cdot\right]$, homeostasis, both of which are likely contributors of neuronal damage. However, glutamate activation may also result in an IEG response, which may in turn trigger various plastic compensatory actions. If indeed glutamate is dual in its function, then MK-801 may well abolish both the neurotoxic and the plastic compensatory action of glutamate, while gangliosides likely abate only the glutamate neurotoxicity while opening the transcription-activating action of glutamate that may operate in neuronal plasticity. This inference implies that the activation of IEG is not part of the mechanism of glutamate neurotoxicity as inferred by the protective action of gangliosides and MK-801, two drugs that protect equally well from neurotoxicity, yet act differentially on the IEG response.

\section{References}

Armstrong DM, Terry RD, DeTeresa RM, Bruce G, Hersh LB, Gage FH (1987) Response of septal cholinergic neurons to axotomy. J Comp Ncurol 264:42!-436.

Astrup J, Siesjo BK, Symon L (1981) Thresholds in cerebral ischemia. The ischemia penumbra. Stroke 12:723-725.

Benveniste H, Drejer J, Schousboe A, Diemer NH (1984) Elevation 
of the extracellular concentration of glutamate and aspartate in rat hippocampus during transient cercbral ischemia monitored by intracerebral microdialysis. J Neurochem 43:1369-1374.

Bredt DS. Snyder SH (1992) Nitric oxide, a novel neuronal messenger. Neuron 8:3-11.

Candeo P, Favaron M, Lengyel I, Manev RM, Rimland JM, Manev H (1992) Pathological phosphorylation causes neuronal death: effect of okadaic acid in primary culture of cerebellar granule cells. J Neurochem 59:1558-1561.

Cardell M, Bingren H, Wieloch T, Zivin J, Saitoh T (1990) Protein kinase $\mathrm{C}$ is translocated to cell membranes during cerebral ischemia. Neurosci Lett 119:228-232.

Carolei A, Fieschi C, Bruno R, Toffano G (1991) Monosialoganglioside GM1 in cerebral ischemia. Cerebrovasc Brain Metab Rev 3:134157.

Cheng B, Mattson MP (1991) NGF and bFGF protect rat hippocampal and human cortical neurons against hypoglycemic damage by stabilizing calcium homeostasis. Neuron 7:1031-1041.

Choi DW (1988) Glutamate neurotoxicity and diseases of the nervous system. Neuron 1:623-634.

Choi DW, Rothman SM (1990) The role of glutamate neurotoxicity in hypoxic-ischemic neuronal death. Annu Rev Neurosci 13:171182.

Comelli MC, Scren MS, Guidolin D, Mancv RM, Favaron M, Rimland JM, Canella R, Negro A, Manev H (1992) Photochemical stroke and brain-derived neurotrophic factor (BDNF) mRNA expression. Neuroreport 3:437-476.

Connor JA (1992) In pursuit of neuronal calcium: confessions of a bio-optician. In: Fidia Research Foundation Neuroscience Award Lectures, Vol 6, pp 111-139. New York: Raven.

Crumrine RC, Dubyak G, LaManna JC (1990) Decreased protein kinase $\mathrm{C}$ activity during cerebral ischemia and after reperfusion in the adult rat. J Neurochem 55:2001-2007.

Dal Toso R, De Bernardi MA, Brooker G, Costa E, Mocchetti I (1988) Beta adrenergic and prostaglandin receptor activation increases nerve growth factor mRNA content in C6-2B rats astrocytoma cells. J Pharmacol Exp Ther 246:1190-1193.

De Erausquin GA, Manev H, Guidotti A, Costa E, Brooker G (1990) Gangliosides normalize distorted single-cell intracellular free $\mathrm{Ca}^{2}{ }^{2}$ dynamics after toxic doses of glutamate in cerebellar granule cells Proc Natl Acad Sci USA 87:8017-8021.

De Ryck M (1990) Animal models of cercbral stroke: pharmacological protection of function. Eur Neurol 30:21-27.

Dietrich WD, Ginsberg MD, Busto R, Watson BD (1986) Photochemically induced cortical infarction in the rat. I. Time coursc of hemodynamic consequences. J Cereb Blood Flow Metab 36:184-194.

Dietrich WD, Busto R, Watson BD, Scheinberg P, Ginsberg MD (1987) Photochemically induced cerebral infarction. II. Edema and bloodbrain barrier disruption. Acta Neuropathol (Berl) 72:326-334.

Domanska-Janik K, Zalewska T (1992) Effect of brain ischemia on protein kinase $C$. J Neurochem 58:1432-1439.

Eamest DJ, Iadarola M, Yeh HH, Olschowka JA (1990) Photic regulation of $c$-fos expression in neuronal components governing the entrainment of circadian rhythms. Eur Neurol 109:353-361.

Favaron M, Manev H, Alho H, Bertolino M, Ferret B, Guidotti A, Costa E (1988) Gangliosides prevent glutamate and kainate neurotoxicity in primary neuronal cultures of neonatal rat cerebellum and cortex. Proc Natl Acad Sci USA 85:7351-7355.

Favaron M, Manev H, Siman R, Bertolino M, Szekely AM, DeErausquin $G$, Guidotti A, Costa $E$ (1990) Down-regulation of protein kinase $C$ protects cerebellar granule neurons in primary culture from glutamate-induced neuronal death. Proc Natl Acad Sci USA 87: 1983-1987.

Fonnum F (1991) Neurochemical studies on glutamate-mediated neurotransmission. In: Fidia Research Foundation symposium series, Vol 5 , Excitatory amino acids (Meldrum BS, Moroni F, Simon RP, Woods JH, eds), pp 15-25. New York: Raven.

Ginsberg MD, Busto R (1989) Rodent models of cercbral ischemia. Stroke 20:1627-1642.

Greenberg JH, Komatsumoto S, Hickey W, Reivich M (1987) The effect of chronic treatment of GMI in a focal ischemia model in cat. In: Fidia research series, Vol 12, Neuroplasticity: a new therapeutic tool in the CNS pathology (Masland RL, Portera-Sanchez A, Toffano G, eds), pp 97-102. Padova: Livana.
Hannun YA, Bell RM (1987) Lysosphingolipids inhibit protein kinase C: implication for the sphingolipidoses. Science 235:670-674.

Honore T, Sheardown MJ, Nielsen EB, Judge ME, Jacobsen P (1991) Quinoxalinediones. Non- $N$-methyl-D-aspartate receptor antagonists as potential drug candidates. In: Fidia Research Foundation symposium serics, Vol 5, Excitatory amino acids (Meldrum BS, Moroni F. Simon RP, Woods JH, cds), pp 451-460. New York: Raven.

Hsu SM, Raine L (1981) Protein A, avidin, and biotin in immunohistochemistry. J Histochem Cytochem 29:1349-1353.

Joo F, Tosaki A, Olah Z, Koltai M (1989) Inhibition by II-7 of the protein kinase C prevents formation of brain edema in SpragueDawley CFY rats. Brain Res 490:141-143.

Karpiak SE, Mahadic SP, Wakade CG (1990) Ganglioside reduction of ischemic injury. CRC Crit Rev Neurobiol 5:221-237.

Kemp JA, Foster AC, Wong EHF (1987) Non-competitive antagonists of excitatory amino acid receptors. Trends Neurosci 10:294-298.

Leon A, Lipartiti M, Seren MS, Laz:zaro A, Mazzari S, Koga T, Toffano G. Skaper SD (1990) Hypoxic-ischemic damage and the neuroprotective effects of GM1 ganglioside. Stroke [Suppl] 21:III 95-III 97.

Louis JC, Magal E, Yavin E (1988) Protein kinase C altcrations in the fetal rat brain after global ischemia. J Biol Chem 263:19282-19285.

Magal E, Louis JC, Aguilera J, Yavin E (1990) Gangliosides prevent ischemia-induced down-regulation of protein kinase $\mathrm{C}$ in fetal rat brain. J Neurochem 55:2126-2131.

Manev H, Favaron M, Guidotti A, Costa E (1989) Delayed increase of $\mathrm{Ca}^{2+}$ influx elicited by glutamate: role in neuronal death. Mol Pharmacol 36:106-112.

Manev H, Costa E, Wroblewski JT, Guidotti A (1990a) Abusive stimulation of excitatory amino acid receptors: a strategy to limit neurotoxicity. FASEB J 4:2789-2797.

Manev H, Favaron M. Vicini S, Guidotti A, Costa E (1990b) Glutamate-induced neuronal death in primary cultures of cerebellar granule cells: protection by synthetic derivatives of endogenous sphingolipids. J Pharmacol Exp Ther 252:419-427.

Mao J, Donald DD, Mayer DJ, Hayes RL (1992) Pain-related increase in spinal cord membrane-bound protein kinase $C$ following peripheral nerve injury. Brain Res 588:144-149.

Marlier L, Tcilhac JR, Ccrruti C, Privat A (1991) Autographic mapping of $5-\mathrm{HT}_{1}, 5-\mathrm{HT}_{1 \mathrm{~A}}, 5-\mathrm{HT}_{1 \mathrm{~B}}, 5-\mathrm{HT}_{2}$ receptors in the rat spinal cord. Brain Res 550:15-23.

Mattson MP (1991) Evidence for the involvement of protein kinase $C$ in neurodegenerative changes in cultured human cortical neurons. Exp Neurol 112:95-103.

Mcmo M, Bovolin P, Costa E, Grayson DR (1991) Regulation of gamma-aminobutyric acid, receptor subunit expression by activation of $N$-methyl-D-aspartate-selective glutamate receptor. Mol Pharmacol 39:599-603.

Miller RJ (1992) Neuronal $\mathrm{Ca}^{2}{ }^{2}$ : getting it up and keeping it up. Trends Neurosci 15:317-319.

Muller W, Connor JA (1991) Dendritic spines as individual neuronal compartments for synaptic $\mathrm{Ca}^{2+}$ responses. Nature 354:73-76.

Nabeshima T, Ogawa S, Nishimura H, Fuji K, Kameyama T, Sasaki Y (1991) Staurosporine, a protein kinase inhibitor, attenuates basal forebrain-lesion-induced amnesia and cholinergic neuronal deficit. Neurosci Lett 122:13-16.

Nishizuka Y, Shearman MS, Oda T, Berry N, Shinomura T, Asaoka Y, Ogita K, Koide H, Kikkawa U, Kishimoto A, Kose A, Saito N, Tanaka C (1991) Protein kinase C family and nervous function. Prog Brain Res 89:125-141.

Ohno M, Yamamoto T. Watanabe S (1991) Effect of staurosporine, a protein kinase $C$ inhibitor, on impairment of working memory in rats exposed to cerebral ischemia. Eur $J$ Pharmacol 204:113-116.

Olah Z, Ikeda J, Anderson WB, Joo F (1990) Altered protein kinase $C$ activity in different subfields of hippocampus following cerebral ischemia. Neurochem Res 15:515-518.

Onodera H, Araki T, Kogure K (1989) Protein kinase C activity in the rat hippocampus after forebrain ischemia: autoradiographic analysis by [ ${ }^{3} \mathrm{H}$ ]phorbol 12,13 dibutyrate. Brain Res 481:1-7.

Paxinos $G$, Watson $C$ (1982) The rat brain in stereotaxic coordinates. Sydney: Academic.

Pierpaoli C, Righini A, Linfante I, Alger JR, Di Chiro G (1992) Diffusion and T2 weighted MRI in a model of focal cortical ischemia in rats. Soc Neurosci Abstr 18:1264.

Polo A, Kirschncr G, Guidotti A, Costa E (1992) Brain content of 
glycosphingolipids after oral administration of monosialogangliosides (GM1) derivatives. Soc Neurosci Abstr 18:1602.

Rothman SM, Olney JW (1986) Glutamate and the pathophysiology of hypoxic-ischemic brain damage. Ann Neurol 19:105-111.

Rothman SM, Olney JW (1987) Excitotoxicity and the NMDA receptor. Trends Neurosci 10:299-302.

Sheardown MJ, Nielsen EO, Hansen AJ, Jacobsen P, Honore T (1990) 2,3-Dihydroxy-6-nitro-7-sulfamoyl-benzo(F)quinoxaline: a ncuroprotectant for cerebral ischemia. Science 247:571-574.

Siesjo BK, Bengtsson F (1989) Calcium fluxes, calcium antagonists and calcium-related pathology in brain ischemia, hypoglycemia and spreading depression: a unifying hypothesis. J Cereb Blood Flow Metab 2:127-140.

Siesjo BK, Agardh CD, Bengtsson F (1989) Free radicals and brain damage. Cerebrovasc Brain Metab Rev 1:165-211.

Szekely AM, Barbaccia ML, Costa E (1987) Activation of specific glutamate receptor subtypes increases $c$-fos proto-oncogene expression in primary cultures of cerebellar granule cells. Neuropharmacology 26:1779-1782.

Szekely AM, Costa E, Grayson DR (1990) Transcriptional program coordination by $N$-methyl-D-aspartate-sensitive glutamate receptor stimulation in primary cultures of cerebellar granule cells. Mol Pharmacol 38:624-633.

Vaccarino F, Guidotti A, Costa E (1987) Ganglioside inhibition of glutamate-mediated protein kinase $\mathrm{C}$ translocation in primary cultures of cerebellar neurons. Proc Natl Acad Sci USA 84:8707-8711.

Watson BD, Dietrich WD (1990) Animal models in stroke. Stroke 21: 1376-1377.

Watson BD, Dietrich WD, Busto R, Wachtel MS, Ginsberg MD (1985) Induction of reproducible brain infarction by photochemically initiated thrombosis. Ann Neurol 17:497-504.

Wong EHF, Kemp JA, Priestley T, Knight AR, Woodruff GM, Iversen LL (1986) The anticonvulsant MK-801 is a potent $N$-methyl-D-aspartate antagonist. Proc Natl Acad Sci USA 83:7104-7108.

Worley PF, Baraban JM, Snyder SH (1986) Heterogeneous localization of protein kinase $\mathrm{C}$ in rat brain: autoradiographic analysis of phorbol ester receptor binding. J Neurosci 6:199-207.

Zivin JA, Kochhar A, Saitoh T (1990) Protein phosphorylation during ischemia. Stroke [Suppl III] 21:117-121. 